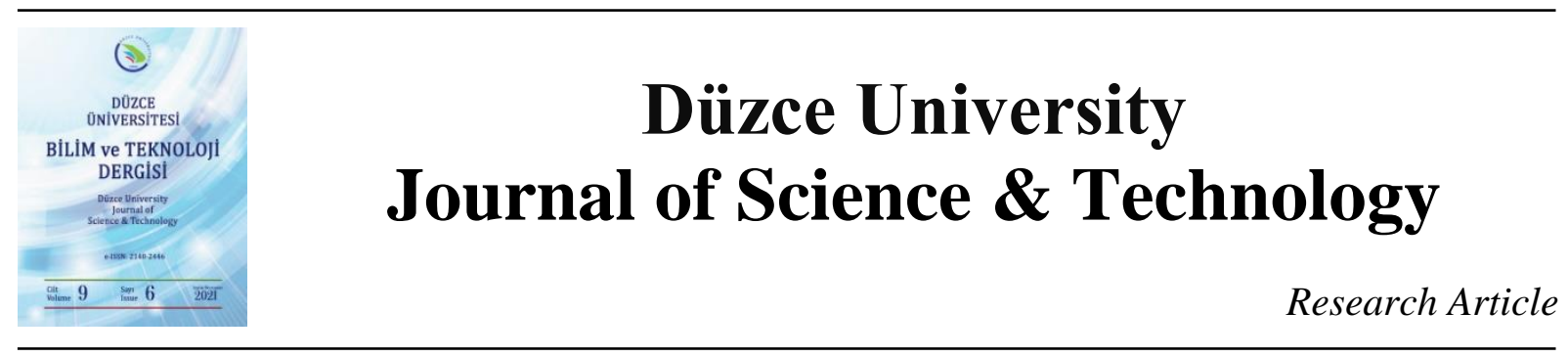

\title{
Application of Reconstruction Algorithms by Simulation Experiments for the Diagnosis of Breast Tumor-Like Tissues Modeled in Diffuse Optical Tomography ${ }^{1}$
}

\author{
Dençay SEVIM ${ }^{\mathrm{a}, \mathrm{b}, *}$, (D) Yiğit Ali ÜNCÜ ${ }^{\mathrm{c}}$, (D) Murat CANPOLAT ${ }^{\mathrm{c}}$ \\ ${ }^{a}$ Health Services and Techniques, Vocational School of Medical Services, Ufuk University, Ankara, TURKEY \\ ${ }^{b}$ Nanotechnology, Department of Advanced Technologies, Eskisehir Technical University, Eskisehir, TURKEY \\ ${ }^{c}$ Biomedical Optics Research Unit, Department of Biophysics, School of Medicine, Akdeniz University, Antalya, \\ TURKEY \\ * Corresponding author's e-mail address: gencay.sevim@ufuk.edu.tr
} DOI: 10.29130/dubited.1016284

\begin{abstract}
In Diffuse Optical Tomography (DOT), data processing and reconstruction stages are crucial to obtain high-quality images. Thus, choosing suitable algorithms for the system is a critical choice. This study aims to determine an appropriate reconstruction algorithm for DOT imaging. There are several reconstruction algorithms used in DOT systems. Some algorithms have been improved for solving specific cases, and some still need to be improved. In this study, we used three algorithms for the reconstruction process: Singular Value Decomposition (SVD), BiConjugated Gradient (Bi-CG), and Transpose Free Quasi Minimal Residual (TFQMR). In testing the algorithms, data of the simulation experiments have been used. The simulation experiments model the tumoral tissue within the breast. All three algorithms were produced correct images while the tumor close to the surface. In the case of the tumor that is not close to the breast surface, the tumor location on the images created by Bi-CG and SVD algorithms was not its actual location. However, the tumor location in the image created by the TFQMR algorithm was close to its actual location. Outcomes of the reconstruction algorithms were evaluated based on correctly defining the location of the tumors by using Mean Percentage Error (MPE), Mean Squared Error (MSE), and Mean Absolute Error (MAE) metrics. We have demonstrated the TFQMR algorithm is a more appropriate reconstruction technique for DOT systems. Thus, we have concluded that TFQMR can have the potential to be used in medical imaging systems.
\end{abstract}

Keywords: Reconstruction Algorithm, Singular Value Decomposition, Bi-Conjugated Gradient, Transpose Free Quasi Minimal Residual

\section{Difüz Optik Tomografi' de Modellenmiş Meme Tümörü Benzeri Dokuların Teşhisi için Simülasyon Deneyleriyle Geri Çatım Algoritmalarının Uygulanması}

\begin{abstract}
$\underline{\mathrm{OZZ}}$
Difüz Optik Tomografide (DOT), yüksek kaliteli görüntüler elde etmek için veri işleme ve geri çatım aşamaları çok önemlidir. Bu nedenle, sistem için uygun algoritmaların belirlenmesi kritik bir seçimdir. Bu çalışma, DOT görüntüleme için uygun bir geri çatım algoritmasını belirlemeyi amaçlamaktadır. DOT sistemlerinde kullanılan birçok geri çatım algoritması vardır. Bazı algoritmalar belirli özel durumları çözmek için geliştirilmiştir ve bazılarının da hala iyileştirilmesi gerekmektedir. Bu çalışmada, geri çatım işlemi için üç algoritma kullanılmıştır; Tekil Değer Ayrışımı (SVD), Bi-Konjuge Gradyan (Bi-CG) ve Transpozesiz Yarı Minimal Rezidüel (TFQMR). Algoritmaların test edilmesinde simülasyon deneylerinin verileri kullanılmıştır. Simülasyon deneyleri, meme içindeki tümör dokusunu modellemektedir. Her üç algoritma da tümör yüzeye yakınken gerçeğe daha yakın
\end{abstract}

${ }^{1}$ This study was presented in ICAIAME 2021 and published as summary text. 
görüntüler üretmiş̧tir. Tümörün meme yüzeyine yakın olmaması durumunda ise, Bi-CG ve SVD algoritmaları ile oluşturulan görüntülerdeki tümör konumu gerçek konumu değildir. Ancak TFQMR algoritması ile olușturulan görüntüdeki tümör konumu, gerçek konumuna yakın elde edilmiștir. Geri çatım algoritmalarının sonuçları, Ortalama Yüzde Hata (MPE), Ortalama Kare Hata (MSE) ve Ortalama Mutlak Hata (MAE) metrikleri kullanılarak tümörlerin lokasyonunun doğru tanımlanmasına dayalı olarak değerlendirilmiştir. TFQMR algoritmasının DOT sistemleri için daha uygun bir geri çatım tekniği olduğu gösterilmişsir. Böylece, TFQMR'nin tıbbi görüntüleme sistemlerinde kullanılma potansiyeline sahip olabileceği sonucuna varıldı.

Anahtar Kelimeler: Geri Çatım Algoritması, Tekil Değer Ayrışımı, Bi-Konjuge Gradyan, Transpozesiz Yarı Minimal Rezidüel

\section{INTRODUCTION}

Diffuse Optic Tomography (DOT) is an alternative to other medical imaging systems for imaging biological tissues. DOT systems perform in different ways: Time-Domain, Frequency-Domain, Continuous-Wave (CW), and Hybrid [1]-[5].

We have designed our system as a Continuous-Wave Diffuse Optic Tomography (CW-DOT) [5]. CWDOT systems also emit a constant amplitude of light. It provides to examine a pathological change in tissue by measuring the decrease in the amplitude of the incident light.

In CW-DOT, there are three main processes for imaging tissue. Firstly, the CW-DOT probe collects light distribution data from each biological tissue having specific optical properties such as absorption and scattering coefficients, anisotropy, and refractive indexes [6]. Secondly, Monte Carlo simulations produce a weight matrix. In back reflection DOT systems, the trajectory of the detected photons is in banana shape (it is not a straight line). Therefore, a simulation is required to create the weight matrix [7]. Finally, the reconstruction process is used for solving the linear equation system referring to light distribution within a medium. The radiative transfer equation mathematically models the light distribution in the tissue [6], but the equation is difficult to calculate. Therefore, diffusion approximation can reduce it to the diffusion equation [2]. Furthermore, applying some mathematical approximations to the equation linearizes it. The reconstruction process is applied to find the unknown matrix by solving the linear equation system, which allows obtaining an image of the tissue [1], [2].

DOT has become one of the alternative diagnostic methods, but it still has many obstacles needed to improve. One of them is the reconstruction process affecting image quality significantly. Recently, many different reconstruction algorithms have been embedded in the DOT systems [1]-[5]. However, every reconstruction algorithm has disadvantages [2], [8], [9]. A reconstruction algorithm cannot solve all matrix systems. For example, Conjugated Gradient (CG)-based algorithms can solve symmetric, positive definite, large sparse matrix systems, but not non-Hermitian [8], [9]. Each algorithm is specific to the system to be used. Therefore, choosing an appropriate reconstruction algorithm for the system is crucial.

In this study, we have designed simulations modeling the breast tissue with a tumor and without it. To reconstruct the breast phantoms, we have used three different algorithms: Singular Value Decomposition (SVD), Bi-Conjugated Gradient (Bi-CG), and Transpose Free Quasi Minimal Residual (TFQMR). We have used the SVD algorithm in this study because it is one of the most used algorithms in imaging systems in the literature. In addition to SVD, CG-based algorithms are also commonly used in many imaging systems. We have used the Bi-CG algorithm among these CG-based algorithms because it was developed for non-Hermitian systems. We have determined that TFQMR produces high-quality images in a previous study [2]. However, we have never evaluated these algorithms with performance metrics before. Therefore, we have evaluated three algorithm with the performance metrics such as Mean Percentage Error (MPE), Mean Absolute Error (MAE), and Mean Squared Error (MSE) [11]-[13]. 


\section{MATERIAL AND METHOD}

\section{A. SIMULATION EXPERIMENTS}

In the simulation experiments, breast and tumoral tissue were modeled with the absorption coefficient of breast and tumoral tissue being $0.04 \mathrm{~cm}^{-1}$ and $0.16 \mathrm{~cm}^{-1}$, respectively. We have simulated breast tumors at different depths. Also, we have counted the number of photons detected from the breast tissue with a tumor and without it separately. Next, we have obtained the perturbation data by subtracting the number of photons obtained from the breast tissue without tumor from those with it. Then, we have used the perturbation data in the reconstruction algorithms.

\section{B. RECONSTRUCTION ALGORITHMS}

In the literature, reconstruction algorithms are used to solve large systems in many fields, including medical imaging systems. However, we used three algorithms: SVD, Bi-CG, and TFQMR techniques.

\section{B. 1. Singular Value Decomposition}

SVD solves large matrix systems by decomposition. In this algorithm, the coefficients are decomposed to form two eigenvectors and one eigenvalue by performing a sort of factorization operation on this matrix to invert a coefficient matrix [14]-[16].

Eigenvector of $A^{T} A$ is $V$, eigenvector of $A A^{T}$ is $U$. Since $A A^{T}=A^{T} A$, the eigenvalues provided by the two eigenvectors are common.

The basis of the algorithm [14]-[16],

$$
A=U S V^{T}
$$

$A^{T} A=V S^{T} U^{T} U S V^{T}=V S^{T} I S V^{T}$

$U^{T} U=I$

$A^{T} A=V S^{T} I S V^{T}=V S^{T} S V^{T}$

Since $S$ is a diagonal matrix, $S S^{T}=S^{T} S=S^{2}$. Then, Eqn. 4 can be written as the equality " $A^{T} A=V S^{2} V^{T}$ ". According to the equation, it is found that $S^{2}$ is eigenvalue and that the vector $V$ is the eigenvector. Likewise, when considering $A A^{T}$;

$A A^{T}=U S V^{T} V S^{T} U^{T}=U S S^{T} U^{T}=U S^{2} U^{T}$

According to Eqn. 5, the eigenvalue of $A A^{T}$ is $S^{2}$, and the eigenvector of $A A^{T}$ is obtained as $U$ [14]-[16].

\section{B. 2. Bi-Conjugated Gradient}

The Bi-CG is also an improved version of the Conjugated Gradient (CG) for the non-Hermitian system. In addition to CG subspaces, there is another subspace of the Bi-CG, which is defined in Eqn. 6 [10], [17].

$$
L_{i}=\operatorname{span}\left(w_{0}, A^{T} w_{0},\left(A^{T}\right)^{2} w_{0}, \ldots,\left(A^{T}\right)^{i-1} w_{0}\right)
$$


Therefore, the Bi-CG does not need an asymmetric coefficient matrix to solve a system. The Bi-CG uses extra two vectors being intrinsic to $L_{i}$ subspace to solve a system (Eqn. 7).

$$
r_{i}^{*}=r_{i-1}^{*}-\alpha_{i} A^{T} p_{i}^{*}, \quad p_{i}^{*}=r_{i-1}^{*}-\beta_{i} p_{i-1}^{*}
$$

where $\alpha$ is a constant of orthogonality relation, and $\beta$ is the Gram-Schmidt constant. During obtaining a solution, the Bi-CG keeps on iterating until it gets a vector meeting the following conditions [10], [17]:

$$
\begin{aligned}
& \left(r_{i}^{*}, r_{j}\right)=0, i \neq j \\
& \left(p_{i}^{*}, A p_{j}\right)=0, i \neq j
\end{aligned}
$$

The Bi-CG algorithm was improved to solve matrices systems with non-Hermitian matrix. However, it is inconsistent due to having a situation called wild oscillation, which causes irregular convergence behavior [8], [9].

\section{B. 3. Transpose Free Quasi Minimal Residual}

The QMR was put forward to be able to solve Bi-CG's irregular convergence behavior problem [9], [18], [19]. However, as in Eqn. 11, while the QMR method solves a matrix system, it needs to use matrix-vector multiplications with the coefficient matrix $(A)$ and its transpose $\left(A^{T}\right)$ [8].

$$
\begin{array}{ll}
\operatorname{span}\left\{v_{1}, v_{2}, \ldots, v_{n}\right\}=K_{n}\left(v_{1}, A\right) & n=1,2, \ldots \\
\operatorname{span}\left\{w_{1}, w_{2}, \ldots, w_{n}\right\}=K_{n}\left(w_{1}, A^{T}\right) & n=1,2, \ldots
\end{array}
$$

The nth Krylov subspace of $C^{N}$ is produced by sequences of vectors $v_{1}, w_{1}$ and the matrices $A$ and $A^{T}$. The QMR produces two sequences of vectors (Eqn. 10,11). To achieve this, it needs transpose of the coefficient matrix. Thus, the TFQMR method was proposed as an alternative method to overcome the problem [8].

In QMR, as in Eqn.12, a nonsingular matrix (S) is used to be able to simplify the Lanczos process, which provides to eliminate transpose in TFQMR by rearranging the initial vector $\boldsymbol{w}_{\mathbf{1}}$ (Eqn. 13) [8], [9], [19].

$$
\begin{aligned}
& A^{T} S=S A, \quad S \in C^{N x N}, \quad v_{1}, w_{1} \in C^{N} \\
& w_{1}:=\frac{1}{\left\|S v_{1}\right\|} S v_{1} \\
& w_{n}=\frac{\gamma_{n}}{\left\|S v_{1}\right\|} S v_{n}=\frac{1}{\left\|S v_{n}\right\|} S v_{n}
\end{aligned}
$$

In other words, the TFQMR converges by rearranging vector sequences of the Conjugate Gradient Squared (CGS) [9], [19]. This arrangement provides smooth convergence and low computational cost [2], [8], [9], [19].

\section{PERFORMANCE EVALUATION}

The error metrics define $e_{t}$ error as the difference between the actual observed value $y_{t}$ and its prediction $\widehat{y_{t}}$ at time $t$. This difference refers to the unpredictable part of the corresponding observation. It can be written as Eqn. 15.

$e_{t}=y_{t}-\widehat{y}_{t}$ 
The error metrics used in these processes are explained and compared in Eqn. 15. All error metrics as MPE, MAE, MSE used in these processes are explained and compared. MPE measures the percentage of the mean difference between predicted values and those observed in Eqn. 16. Therefore, it becomes independent of the measurement scale. Near-zero MPE values mean that the model has no specific bias; it does not provide information about the accuracy performance of the model and weighs all mistakes equally [12].

$$
M P E=\frac{100}{n} \sum_{t=1}^{n} e_{t} / y_{t}
$$

The MAE measures the mean absolute difference between predicted values and those observed. Instead, it measures the overall error of the estimate. Therefore, the smaller the MAE results, the higher success of the model in Eqn. 17 [11].

$$
M A E=\frac{1}{n} \sum_{t=1}^{n}\left|e_{t}\right|
$$

MSE measures the mean square prediction error in Eqn.18. Since the error measure squares the errors, the information about the general error direction is lost. For the same reason, MSE highlights gross errors to penalize overestimation errors, unlike previous error metrics. MSE is not independent of scale, even very sensitive to small-scale differences. Although MSE results are difficult to understand and interpret, it is more useful in the prediction model, especially when large errors are not desired [13].

$$
M S E=\frac{1}{n} \sum_{t=1}^{n} e^{2}
$$

All performance metrics used in this study are useful for a prediction process. Reconstruction algorithms endeavor to solve a matrix system, but they do not provide the exact solution. Therefore, performance metrics can provide information about how close the algorithms are to the solution. All performance metrics have been embedded into three reconstruction algorithms. Because all algorithms are iterative methods, performance metrics are based on the number of iterations that provide the final image.

\section{RESULTS}

A simulation code has been written in MATLAB 2020b to create simulation data. The experimental data have been obtained from simulation experiments in the study. Simulation data, which simulates tumoral tissue, have been generated at different locations (Figure $1(a, b)$ and $2(a, b)$ ). Figures 1 (b) and 2 (b) are the depths at which tumoral tissues have been placed. In addition, the results of performance methods such as MPE, MAE, and MSE have been shown in Tables 1 and 2.

In this experiment, a tumor (its size is $0.4 \times 0.6 \times 0.2 \mathrm{~cm}^{3}$, the depth is $0.2 \mathrm{~cm}$ ) within the breast has been simulated in Figure $1(\mathrm{a}, \mathrm{b})$. Then, images have been reconstructed by three algorithms. Figure $1(\mathrm{c}, \mathrm{d})$ is the $x-y$ and $x-z$ images reconstructed by the SVD algorithm, respectively. Similarly, Figure $1(e, f)$ are images generated by the Bi-CG algorithm, and Figure $1(\mathrm{~g}, \mathrm{~h})$ are images generated by the TFQMR algorithm. There seems to be no significant difference between the reconstructed images. However, when examining the error parameters of the three algorithms (Table 1), it is seen that there is a slight difference. It shows how close the reconstructed images are to the actual simulation image because these error parameters have been calculated according to the numerical data of images. Thus, it indicates that the TFQMR algorithm provides a better solution than other algorithms. 


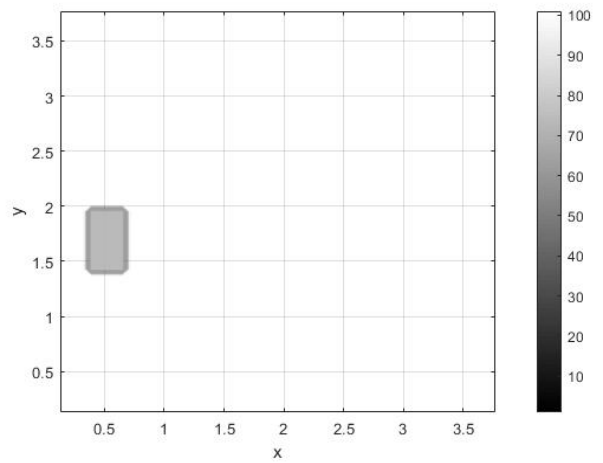

(a)

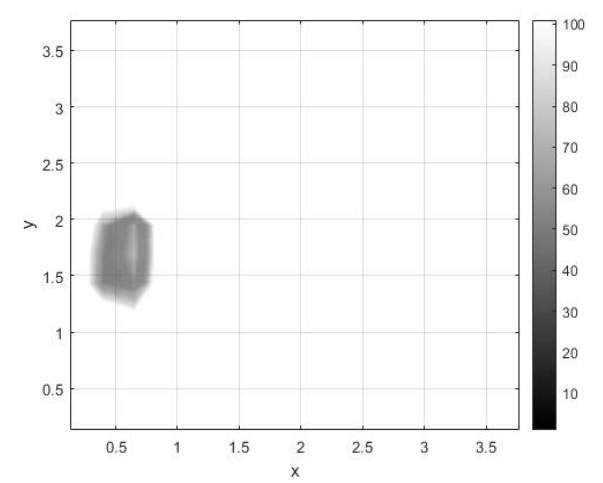

(c)

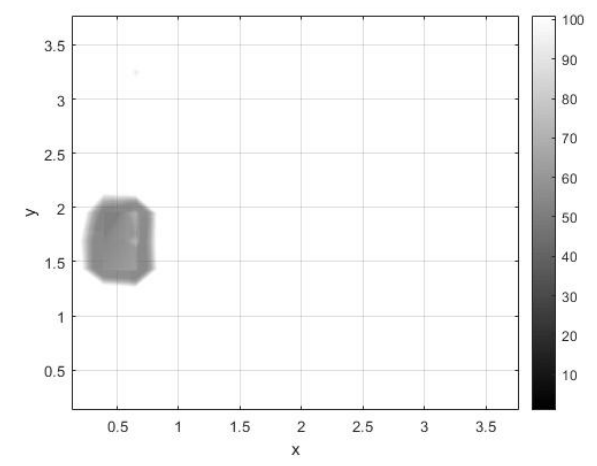

(e)

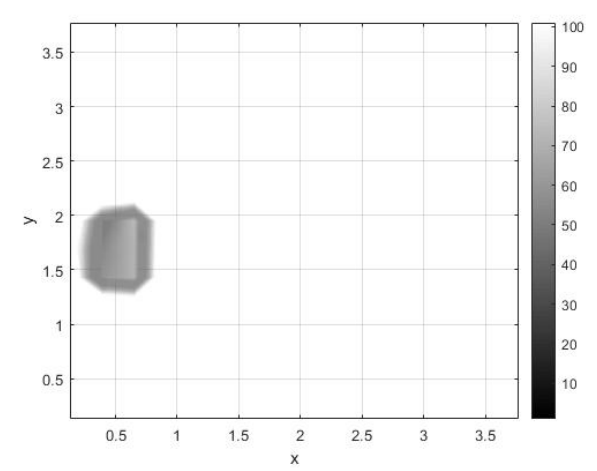

(h)

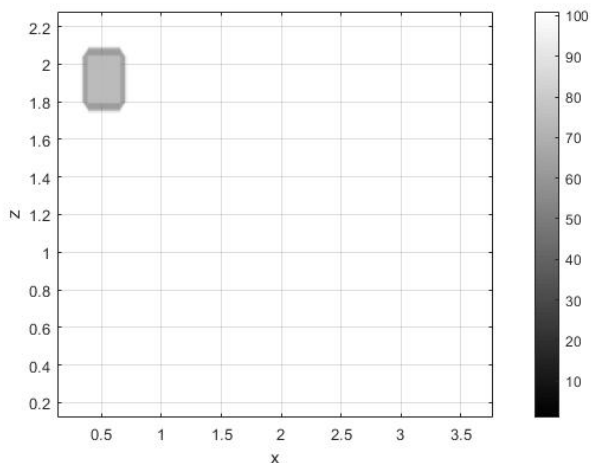

(b)

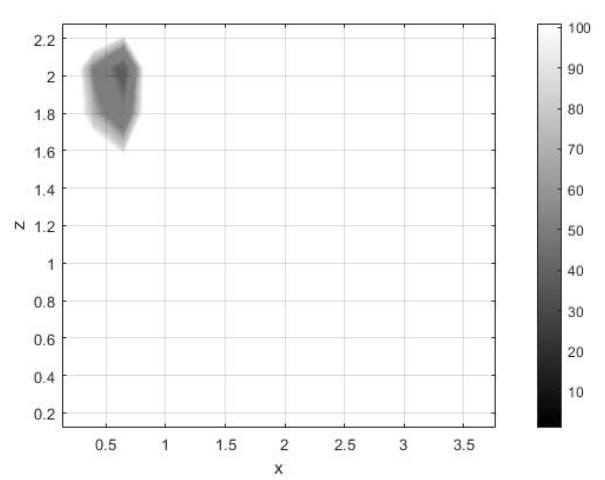

(d)

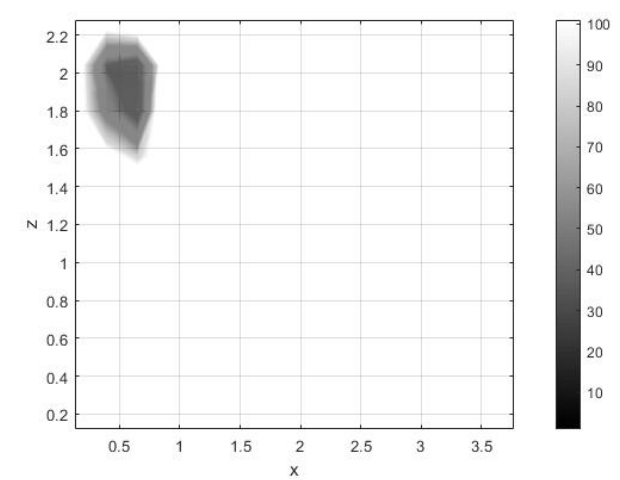

$(f)$

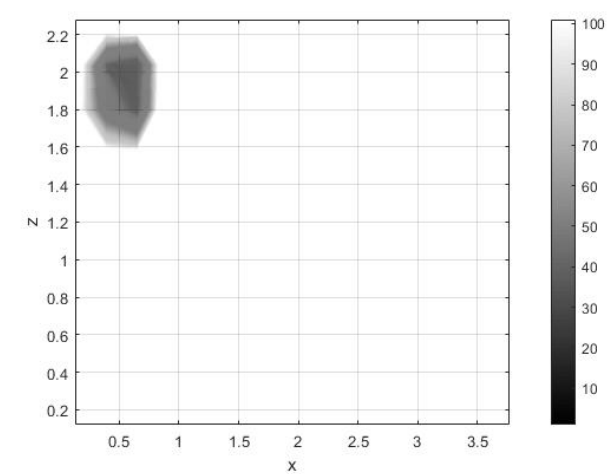

(g)

Figure 1. (a) The $x$-y plane and (b) The $x$-z plane images are the simulation of the tumoral tissue within the breast (1.4 - 2 at $y, 0.3-0.7$ at $x, 1.9-2.1$ at z coordinates), (c) The $x$-y plane (d) The z-x plane images are reconstructed by $S V D$, (e) The $x$-y plane $(f)$ The $x$-z plane images are reconstructed by Bi-CG, $(\mathrm{g})$ is the $x-y$ plane image reconstructed by TFQMR, and (h) is the $x$-z plane image reconstructed by TFQMR. The gray color bars refer to the change of absorption coefficient. 
Table 1. In the first simulation experiment, the mean percentage error, mean absolute error and mean squared error of numerical data of the images were reconstructed by each algorithm according to the numerical data of real simulation. The error parameters were calculated according to the numerical data of the real simulation image and the numerical data of the images reconstructed by algorithms.

\begin{tabular}{cccc}
\hline $\begin{array}{c}\text { Reconstruction } \\
\text { Algorithm }\end{array}$ & $\begin{array}{c}\text { Mean Percentage } \\
\text { Error (MPE) } \\
(\%)\end{array}$ & $\begin{array}{c}\text { Mean Absolute Error } \\
\text { (MAE) }\end{array}$ & $\begin{array}{c}\text { Mean Squared Error } \\
\text { (MSE) }\end{array}$ \\
\hline SVD & 35.2050 & 0.020896 & 0.00055217 \\
\hline Bi-CG & 31.7521 & 0.020063 & 0.00052261 \\
\hline TFQMR & 23.0437 & 0.015721 & 0.00035844 \\
\hline
\end{tabular}

In this experiment, tumoral tissue within the breast tissue was at a depth of $0.7 \mathrm{~cm}$ (Figure $2(\mathrm{a}, \mathrm{b})$ ). As like, Figure 2 (c, d) are images reconstructed by the SVD algorithm, Figure 2 (e, f) are images generated by the Bi-CG algorithm, and Figure $2(\mathrm{~g}, \mathrm{~h})$ are images generated by the TFQMR algorithm. In this experiment, there is a substantial difference between the reconstructed images. There is a significant difference in appearance between the reconstructed images. Even considering the error parameters, we see this more clearly. TFQMR and Bi-CG parameters when the error does not change significantly, but the changes SVD parameters (Table 2). Nevertheless, the TFQMR provides the ideal parameters and generates the best image for this experiment.

Table 2. In the second simulation experiment, the mean percentage error, mean absolute error and mean squared error of numerical data of the images were reconstructed by each algorithm according to the numerical data of real simulation. The error parameters were calculated according to the numerical data of the real simulation image and the numerical data of the images reconstructed by algorithms.

\begin{tabular}{cccc}
\hline $\begin{array}{c}\text { Reconstruction } \\
\text { Algorithm }\end{array}$ & $\begin{array}{c}\text { Mean Percentage } \\
\text { Error (MPE) } \\
(\%)\end{array}$ & $\begin{array}{c}\text { Mean Absolute Error } \\
\text { (MAE) }\end{array}$ & $\begin{array}{c}\text { Mean Squared Error } \\
\text { (MSE) }\end{array}$ \\
\hline SVD & 44.7685 & 0.024262 & 0.00075688 \\
\hline Bi-CG & 31.8817 & 0.020342 & 0.00055855 \\
\hline TFQMR & 23.1503 & 0.016408 & 0.00039433 \\
\hline
\end{tabular}

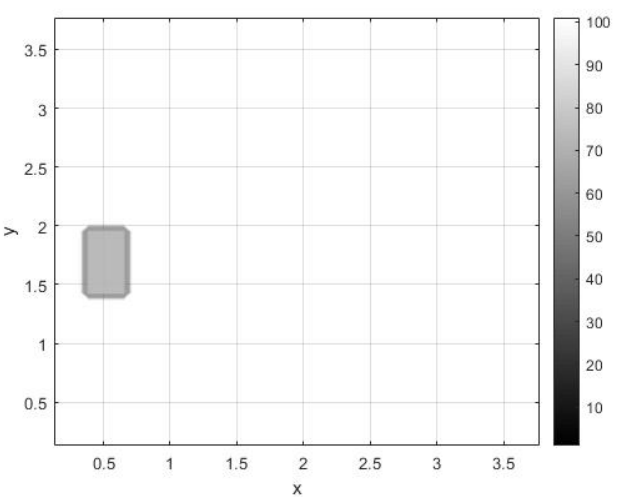

(a)

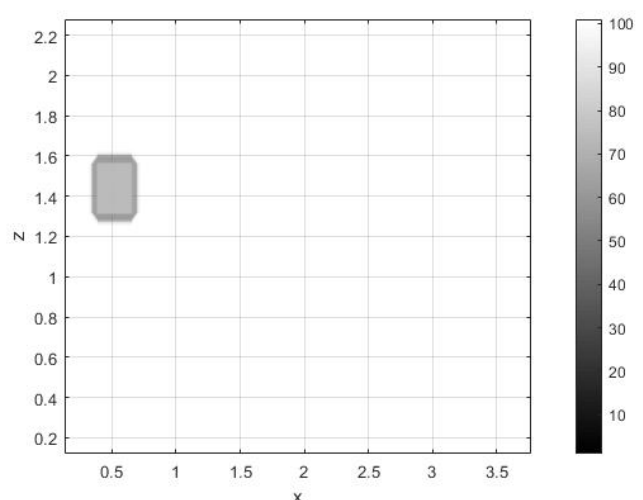

(b) 


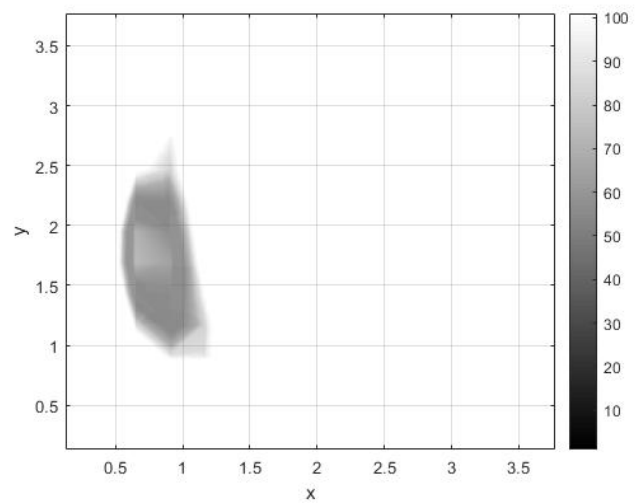

(c)

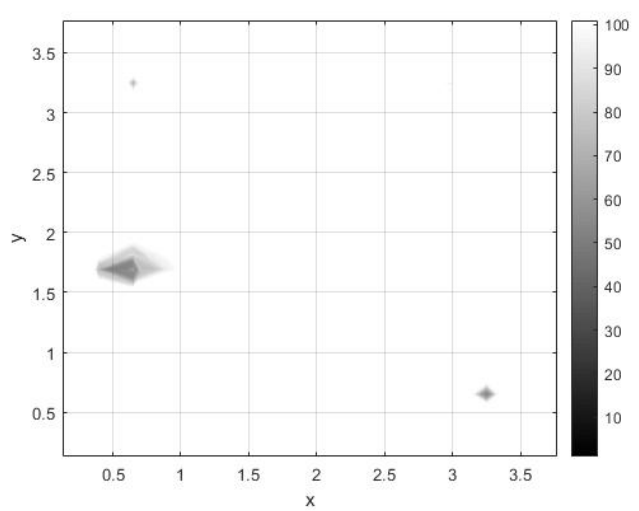

(e)

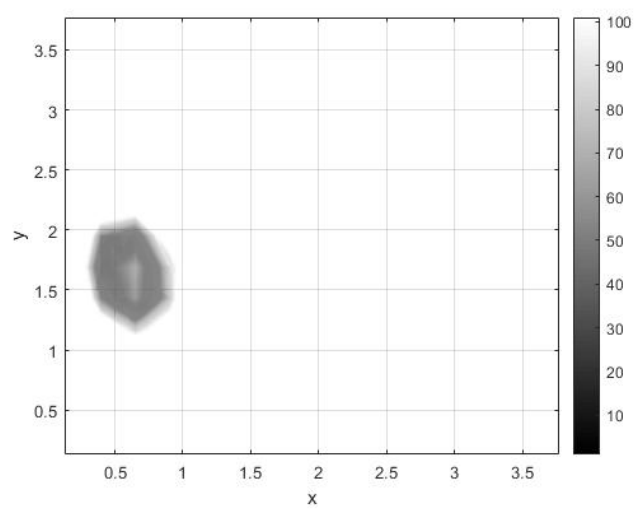

(h)

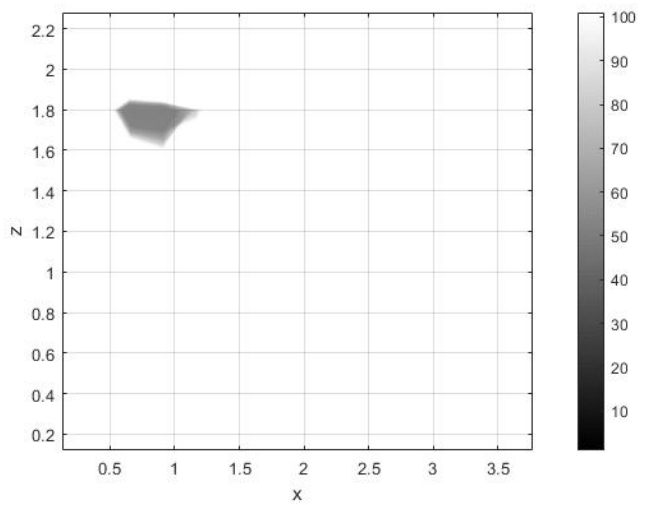

(d)

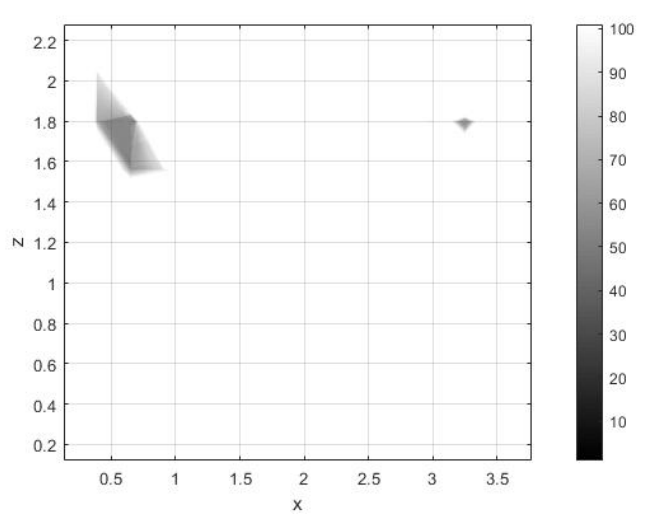

(f)

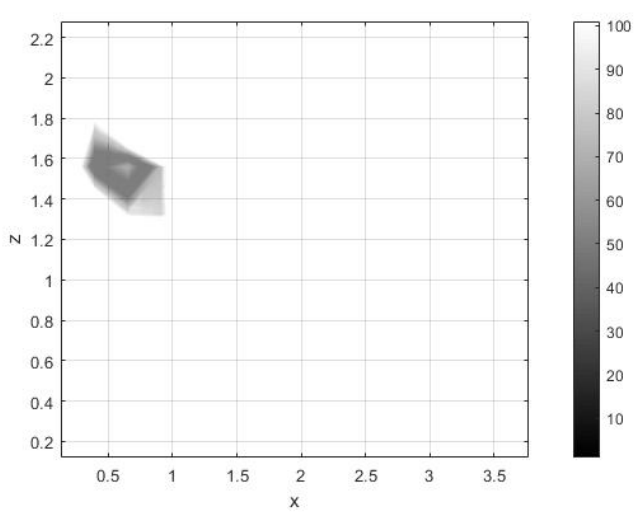

(g)

Figure 2. (a) The $x$-y plane and (b) The $x$-z plane images are the simulation of the tumoral tissue within the breast, $(1.4-2$ at $y, 0.3-0.7$ at $x, 1.3-1.6$ at z) (c) The $x$-y plane (d) The $z$-x plane images are reconstructed by

$S V D,(\boldsymbol{e})$ The $x$-y plane $(\boldsymbol{f})$ The $x$-z plane images are reconstructed by $B i-C G,(g)$ is the $x$-y plane image reconstructed by TFQMR, and $(\boldsymbol{h})$ is the $x$-z plane image reconstructed by TFQMR. The gray color bars refer to the change of absorption coefficient.

\section{CONCLUSION \& DISCUSSION}

The reconstruction of the DOT systems is an essential process affecting image quality, location, resolution. Although several reconstruction algorithms have been used for DOT systems, Krylov subspace algorithms provide a better solution [1], [3]. In our previous studies, we used both algebraic and subspace algorithms [1], [2], [20] - [22]. These algorithms are Algebraic Reconstruction, Simultaneous Iterative Reconstruction, SVD, CG, Bi-CG, and TFQMR techniques. In these studies, we 
compared some algorithms with each other and that some algorithms provide higher quality images for CW-DOT systems. We have shown that CG-based algorithms are superior to algebraic algorithms for CW-DOT systems [1]. Later, we have compared TFQMR with only Bi-CG [2]. In the literature, the CG technique is commonly used as one the most powerful technique to solve large, sparse, positive definite linear systems. The CG provides a solution to Hermitian systems [21], but not non-Hermitian matrix systems [8], [9]. For this case, some algorithms were developed to solve a proper solution system [9], [19]. One of them is the Bi-CG algorithm based on CG. Although Bi-CG solves non-Hermitian systems [10], [17], it has limitations and disadvantages. An algorithm must meet two significant properties to solve non-Hermitian systems. However, the Bi-CG algorithm provides only one; thus, it produces oscillations causing irregular convergence behavior and numerical instabilities [8], [9], [19]. The TFQMR algorithm was developed to overcome the drawback of the Bi-CG [9].

In this study, we have compared three algorithms by examining performance metrics. It has been shown that TFQMR provides a better solution and generates tumor images in actual location and depth than Bi-CG and SVD. TFQMR images have the lowest MPE, MAE, and MSE rates (Table 1 and 2). When considering the results of the reconstruction algorithms, the algorithm with the lowest MSE and MAE ratios is TFQMR. Considering that the MSE value approaches 0 , it is shown as a numerical evaluation that TFQMR is the most successful algorithm among the reconstruction algorithms. When examining both the visual and performance assessment of the experimental results, it is shown that the results obtained with TFQMR were better than the others. Although the simulation experiments are not suitable for the actual breast tissue, simulation experiments have given us information about which algorithm worked well. As a result of the experimental studies, it has been observed that the TFQMR algorithm is suitable for our system.

\section{REFERENCES}

[1] T. Mercan, G. Sevim, Y. A. Üncü, U. Serkan, H. Ö. Kazanc1, and M. Canpolat, "The comparison of reconstruction algorithms for diffuse optical tomography," Süleyman Demirel Üniversitesi Fen Edebiyat Fakültesi Fen Dergisi, vol. 14, no. 2, pp. 285-295, 2019.

[2] G. Sevim, Y. A. Üncü, T. Mercan, and M. Canpolat, "Image reconstruction for diffuse optical tomography using bi-conjugate gradient and transpose-free quasi minimal residual algorithms and comparison of them," International Journal of Imaging Systems and Technology, vol. 31, no. 4, pp. 1894-1905, 2021.

[3] R. J. Gaudette et al., "A comparison study of linear reconstruction techniques for diffuse optical tomographic imaging of absorption coefficient," Physics in Medicine and Biology, vol. 45, no. 4, pp. 1051-70, 2000.

[4] D. A. Boas et al., "Imaging the body with diffuse optical tomography," IEEE Signal Processing Magazine, vol. 18, no. 6, pp. 57-75, 2001.

[5] H. Ö. Kazanc1, T. Mercan, and M. Canpolat, "Design and evaluation of a reflectance diffuse optical tomography system," Optical and Quantum Electronics, vol. 47, no. 2, pp. 257-265, 2015.

[6] S. L. Jacques, "Optical properties of biological tissues: a review," Physics in Medicine \& Biology, vol. 58, no. 11, R37, 2013.

[7] M. Canpolat, "Variation of photon density distribution with system component within Intralipid emulsion," Optik, vol. 122, no. 10, pp. 887-890, 2011.

[8] R. W. Freund and N. M. Nachtigal, "QMR: a quasi-minimal residual method for non-Hermitian linear systems," Numerische Mathematik, vol. 60, no. 1, pp. 315-339, 1991. 
[9] R. W. Freund, "A transpose-free quasi-minimal residual algorithm for non-hermitian linear systems," SIAM Journal of Scientific Computing, vol. 14, no. 2, pp. 470-482, 1993.

[10] R. E. Bank and T. F. Chan, "A composite step bi-conjugate gradient algorithm for nonsymmetric linear systems,” Numerical Algorithms, vol. 7, no. 1, pp. 1-16, 1994.

[11] C. J. Willmott and K. Matsuura, "Advantages of the mean absolute error (MAE) over the root mean square error (RMSE) in assessing average model performance," Climate Reseach, vol. 30, no. 1, pp. 79-82, 2005.

[12] A. de Myttenaere, B. Golden, B. Le Grand, and F. Rossi, "Mean absolute percentage error for regression models," Neurocomputing, vol. 192, pp. 38-48, 2016.

[13] Z. Wang and A. C. Bovik, "Mean squared error: Lot it or leave it? A new look at signal fidelity measures," IEEE Signal Processing Magazine, vol. 26, no. 1, pp. 98-117, 2009.

[14] C. F. Van Loan, "Generalizing the singular value decomposition," SIAM Journal on Numerical Analysis, vol. 13, no. 1, pp. 76-83, 1976.

[15] V. C. Klema and A. J. Laub, "The Singular value decomposition: Its computation and some applications," IEEE Transactions on Automatic Control, vol. 25, no. 2, pp. 164-176, 1980.

[16] S. L. Brunton and J. N. Kutz, "Chapter 1: Singular value decomposition (SVD)," in Data Driven Science \& Engineering: Machine Learning, Dynamical Systems, and Control, Cambridge, 2019, pp. 347.

[17] G. Ortega, E. M. Garzón, F. Vázquez, and I. García, "The BiConjugate gradient method on GPUs," The Journal of Supercomputing, vol. 64, no. 1, pp. 49-58, 2013.

[18] C. Lanczos, "An iteration method for the solution of the eigenvalue problem of linear differential and integral operators," Journal of Research of the National Bureau Standards, vol. 45, no. 4, pp. 255 282, 1950.

[19] R. W. Freund, "Transpose-free quasi-minimal residual methods for non-hermitian linear systems," in Recent Advances in Iterative Methods, New York: Springer, 1994, pp. 69-94.

[20] Y. A. Üncü, G. Sevim, and M. Canpolat, “Approaches to preclinical studies with heterogeneous breast phantom using reconstruction and three-dimensional image processing algorithms for diffuse optical imaging," International Journal of Imaging Systems and Technology, Aug. 2021, doi: https://doi.org/10.1002/ima.22648.

[21] T. Mercan, G. Sevim, H. Ö. Kazanc1, Y. A. Üncü, and M. Canpolat, "Comparison of images produced by diffuse optical tomography with two different backscatter techniques." 21st National Biomedical Engineering Meeting (BIYOMUT), 2018, pp. 1-4.

[22] Y. A. Üncü, G. Sevim, T. Mercan, V. Vural, E. Durmaz, and M. Canpolat, "Differentiation of tumoral and non-tumoral breast lesions using back reflection diffuse optical tomography: A pilot clinical study," International Journal of Imaging Systems and Technology, vol. 31, no. 4, pp. 2023-2031, 2021. 